\title{
The View from Down Under: Freedom of the Press in Canada
}

James Allan

Follow this and additional works at: http://digitalcommons.osgoode.yorku.ca/sclr

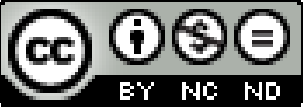

This work is licensed under a Creative Commons Attribution-Noncommercial-No Derivative Works 4.0 License.

\section{Citation Information}

Allan, James. "The View from Down Under: Freedom of the Press in Canada." The Supreme Court Law Review: Osgoode's Annual Constitutional Cases Conference 58. (2012).

http://digitalcommons.osgoode.yorku.ca/sclr/vol58/iss1/5 


\title{
The View from Down Under: Freedom of the Press in Canada
}

\author{
James Allan*
}

In this paper I hope to take a look at the scope of press freedom in certain respects under Canada's entrenched, constitutionalized Canadian Charter of Rights and Freedoms, ${ }^{1}$ and to do so through Australian eyes. Of course I myself am only a transplant to Down Under. If you could hear me you could tell immediately that my speaking voice sounds pretty much the way you would expect from someone who was born and raised in Toronto, went to university at Queen's, married and worked as a lawyer on Bay Street and then moved to London, England to work at the Bar, then moved to Hong Kong for four years, then to New Zealand for eleven, and finally to Australia for the last eight years - always one step ahead of extradition as I like to say.

And all those moves from Hong Kong onwards have been to take up jobs teaching public law in universities. So my accent notwithstanding, I have a lot more experience of constitutional law in the Antipodes than here and also of seeing Canadian constitutional law from an offshore vantage.

My paper will try to give you a taste of that foreigner's perspective by comparing the scope of freedom of the press in Canada, with its Charter, and in Australia where (almost uniquely in the democratic world) there is no national bill of rights of any sort. (And to lay my cards on the table I should tell you straight out that I dislike all types of bills of rights - on democratic grounds ${ }^{2}$ - a view shared by only a small category of legal academics in Canada.)

Garrick Professor of Law, University of Queensland. This paper was first delivered on March 9, 2012 at the Ryerson University "Press Freedom in Canada: A Status Report on the 30th Anniversary of the Charter of Rights and Freedoms" Conference in Toronto. It is made available with the permission of the organizers of that conference. The author thanks Jamie Cameron for her comments on an earlier version of this paper, as well as the participants in the above conference.

Part I of the Constitution Act, 1982, being Schedule B to the Canada Act 1982 (U.K.), 1982, c. 11 [hereinafter "Charter"].

See, e.g., James Allan, "Bills of Rights and Judicial Power - A Liberal's Quandary?" (1996) 16 Oxford J. Legal Stud. 337; James Allan, Sympathy and Antipathy: Essays Legal and Philosophical (Aldershot, U.K.: Ashgate, 2002); James Allan, "Rights, Paternalism, Constitutions 
However, before I move on to the Canada-Australia comparison of the scope of press freedom, I need to do three things. First, I need to give you at least a basic account of why free speech and a free press matter. My answer falls squarely in the utilitarian John Stuart Mill tradition, which argues that in the long term the best consequences for any society flow from allowing the vigorous, untrammelled competition of ideas and views and speech, however hurtful or offensive or character-impugning they might be to some listeners and readers.

If you want to put it in unqualified terms, here is how John Milton did so back in 1644 :

Let Truth and Falsehood grapple; who ever knew Truth put to the worse, in a free and open encounter? (Areopagitica)

Or if you prefer, here is how I would make the point, namely, that the sort of free speech that matters is the kind that offends, disturbs, unsettles and bothers people. A protection or guarantee of free speech where the topic is one everyone agrees about is worthless. It does not do anything. If we are all sitting in a circle, holding hands, with someone strumming on the guitar while we hum "Kumbaya" together then enforceable protections for free speech simply are not needed. You need protections for speech (and newspaper published speech) when the content is not something with which you already agree, when it offends you, when it challenges you, when you would rather not hear it at all.

And the main reason I think this sort of speech needs protecting is the one - as I said — that John Stuart Mill gave. ${ }^{3}$ That the best alternatives or social solutions - or perhaps sometimes the least bad ones -

and Judges" in Grant Huscroft \& Paul Rishworth, eds., Litigating Rights: Perspectives from Domestic and International Law (Oxford and Portland, OR: Hart Publishing, 2002) 29; James Allan, "Oh That I Were Made Judge in the Land" (2002) 30 Fed. L. Rev. 561; James Allan, "Paying for the Comfort of Dogma" (2003) 25 Sydney L. Rev. 63; James Allan, "A Modest Proposal" (2003) 23 Oxford J. Legal Stud. 197; James Allan, “An Unashamed Majoritarian” (2004) 27 Dal. L.J. 537; James Allan, "Portia, Bassanio or Dick the Butcher? Constraining Judges in the Twenty-First Century" (2006) 17 King's College L.J. 1; James Allan, "Thin Beats Fat Yet Again - Conceptions of Democracy" (2006) 25 Law \& Phil. 533; James Allen, "The Victorian Charter of Human Rights and Responsibilities: Exegesis and Criticism" (2006) 30 Melbourne U.L. Rev. 906; "Public Conversation on Constitutionalism and the Judiciary between Professor James Allan and the Honourable Michael Kirby" (2009) 33 Melbourne U.L. Rev. 1032; "Statutory Bills of Rights: You Read Words In, You Read Words Out, You Take Parliament's Clear Intentions and You Shake Them All About - Doin' the Sankey Hanky Panky" in T. Campbell, K. Ewing \& A. Tomkins, eds., The Legal Protection of Human Rights: Sceptical Essays (Oxford: Oxford University Press, 2011) 108; and The Vantage of Law: Its Role in Thinking about Law, Judging and Bills of Rights (Farnham, U.K.: Ashgate, 2011).

3 As in J.S. Mill, On Liberty (first published in 1865). 
will emerge from the cauldron of vigorous, heated debate, mockery and exchange of views. Most speech, most of the time, ought to be tolerated.

A corollary of that is that all of us living in free, democratic societies have an obligation to grow thick skins, to toughen up. We do not get the misguided luxury of playing the victim, of stifling talk and words that we find hurtful. And we don't get that luxury because every once in a while - no one knows for sure when - those hurtful words are making a powerful point - as they did, say, in the U.S. South in the 1950s and 1960 s.

No one can expect good long-term consequences to flow when government and bureaucrats and overzealous human rights commissioners become the arbiters of what can and cannot be said. ${ }^{4}$

So having plenty of scope for citizens in a democracy to speak their minds matters, and it matters however seemingly misguided, erroneous and distasteful their words might be. And notice that saying that is wholly consistent with accepting that no society will ever be able to make the entitlement of free speech an absolute right. Even in the U.S., where at least in formal legal terms there is more protection of speech than anywhere else on the planet, even there there is no protection for speech that counsels murder or details how to make some virulent biological weapon or much else besides.

We are talking relativities here. We may trade scope to speak off against the clear need to stop counselling a likely murder, or even a knowingly false statement aimed at character assassination. But we want the line drawn with as much protection for speech as we can stomach when it comes to words we merely disagree with or find offensive. The long-term good consequences of this are simply too clear and too valuable.

So that is why I think free speech matters. And, as everyone attending a symposium on freedom of the press already realizes, a free press lies at the very heart of any tolerably functioning social system protecting free speech. Indeed, in practical terms a free press is the most important aspect of living in a society that affords lots of scope to free speech.

That was my first preliminary point, setting out why free speech and a free press matter.

$4 \quad$ Those comments should make it plain that I am a strong opponent of the Macleans/Mark Steyn type speech suppressing litigation which I elaborate upon below. 
The second thing I need to do before embarking on a CanadianAustralian free press comparison is to show you, briefly, just how constitutionally similar these two countries are in terms of history and political structure. Pick the country in the world most similar to Canada and it would be Australia.

Why? Well, they are both products of the British Empire, with all the shared history that entails. In particular, that means that they share the common law, a Westminster parliamentary system of government, a myriad of shared political conventions, and the same head of state to this day. They are also both very, very large countries with federal (not unitary) systems, though when the Australian founding fathers came to choose what sort of federal system to have in the late 1890s they opted for the American model over the Canadian one. ${ }^{5}$

Likewise, both Canada and Australia are bicameral (or two legislative chambers) systems, though again the Australian founding fathers shunned the Canadian/United Kingdom model of an unelected Upper House in favour of the American model of an elected Genuine Upper House of Review that looks palatable in the democratic era. ${ }^{6}$

I suppose while mentioning differences I might add that Australia's constitutional amending formula, section 128 of its Constitution that requires a national referendum (with a proposed amendment needing 50 per cent plus one of voters nationally as well as in over half the states), was copied from Switzerland (with Canada's and America's "ask-thepoliticians-only" models being rejected) so as to introduce a dollop of direct democracy into attempts to amend the Constitution Down Under. And Australia operates a compulsory voting system, which I did not much like when I arrived Down Under but now have changed my mind about and think preferable. ${ }^{7}$ At the very least it avoids the now abysmal Canadian voter turnout figures while leaving political parties free to concentrate on their message rather than putting lots of resources into getting out the vote.

Yet those differences notwithstanding, Australia is clearly and undoubtedly Canada's closest cousin in overall constitutional terms.

\footnotetext{
5 So the Australian drafters opted for a list of enumerated powers for the central government alone, the residue going to the states, rather than the Canadian-style option of enumerating the powers of both the centre and the provinces.

In Australia, as in the U.S., each state is given the same number of senators. In Australia it is currently 12 senators for each state, with only six contesting each election on a rolling basis.

$7 \quad$ See James Allan, “In Praise of Compulsory Voting” (May 2012) 56 Quadrant 36.
} 
That brings us to the last of my preliminary points, namely, a few words about the Charter. Now truth be told, and whatever well-founded patriotism might incline you to think, the Charter has not travelled particularly well. Canada's model of a bill of rights was explicitly rejected by New Zealand in 1990 and by the United Kingdom in 1998. It was seen as too potent in terms of transferring power to unelected judges to draw debatable, disputed policy lines over a host of social issues about which smart, well-informed, nice people simply disagree. ${ }^{8}$

Put more bluntly, the Charter was seen as just as counter-majoritarian as the U.S. Bill of Rights, notwithstanding the section 33 notwithstanding clause, which most everyone by now realizes has never once been used at the federal level - not one single time in three decades.

Whether one happens to agree with that democracy-enervating characterization of the Charter or not (and I do), the fact remains it is not a much-copied model. If you find that claim too provocative then let us say that the power to strike down or invalidate legislation is not much copied in the Commonwealth. And when it comes to Australia the Charter and its judicial power-enhancing effects were regularly cited by opponents during recent attempts to adopt or enact some sort of bill of rights.

In fact, Australia's history as regards attempts to achieve some sort of bill of rights is basically this: there have been two constitutional amendment referenda asking the voters if they want one, the most recent in 1988. Both lost badly, the 1988 one losing in every single state in Australia. And with any Canadian or U.S.-style constitutional bill of rights thereby off the table (and it would be a fun counter-factual to wonder if Pierre Trudeau could have got the Charter through if he had had to get the agreement of a majority of voters nationally and in a

\footnotetext{
8 There is a school of thought that points to overseas citations of Canadian Charter decisions to argue that it is, contrary to my views above, a much copied or mimicked instrument. I think that view is wrong for two main reasons. First, Canada's two-stage Charter analyses - where most of the work is done in stage 2 when assessing s. 1 reasonableness - make it easier to make (and hence have cited elsewhere) expansive obiter rights comments than in the U.S., where all the work of deciding if a right applies and what limitation is reasonable is done in one stage. (See my review of Kent Roach's The Supreme Court on Trial: Judicial Activism or Democratic Dialogue? (Toronto: Irwin, 2001), in "The Author Doth Protest Too Much, Methinks" (2003) 20 N.Z.U.L. Rev. 519.) Second, there is in my view a clear ratchet-up effect when it comes to courts citing overseas rights decisions, and this is combined with a cherry-picking effect - the core point being that the overseas judgment is not driving the decision, it is window-dressing for a view reached on other grounds. This argument is made in James Allan, Grant Huscroft \& Nessa Lynch, "The Citation of Overseas Authority in Rights Litigation in New Zealand: How Much Bark? How Much Bite?” (2007) 11 Otago L. Rev. 433.

9 See James Allan, "You Don't Always Get What You Pay For: No Bill of Rights for Australia" (2010) 24 N.Z.U.L. Rev. 179.
} 
majority of provinces, the Australian amending requirement), proponents shifted to arguing for a New Zealand-style statutory bill of rights, especially after 2007 and the election of a seemingly pro-bill of rights Labor government. But public opposition was too great to proceed even with that model. ${ }^{10}$

A Canadian audience may well find the concept of opposing a bill of rights sufficiently unfathomable to want to ask why anyone would do such a thing, so let me highlight the main grievances. The core of the case against is that all rights in a bill of rights - and none more so than the right to free speech - embody vague, amorphous moral abstractions pitched at such a high level of indeterminacy that they effectively finesse all disagreement. Bills of rights are articulated up in the Olympian heights of moral abstractions (right to free speech, right to equality, and so on) where all is consensus and agreement, but they have real effect down in the quagmire of detail (where to draw the lines in a defamation regime or campaign finance system or setup that outlaws speech that is hateful, to stay only within the confines of a free speech entitlement). And down in that quagmire of social policy line-drawing details what you have is inevitable disagreement between people just as nice and as smart and as well-meaning as you, and yes, as some committee of exlawyer judges. ${ }^{11}$

So if you believe in democracy ${ }^{12}$ a bill of rights is highly problematic - unless you just suppose or assume that the 5-4 decision of a top court has some mystical correlation with what actually is the timeless, fundamental rights-respecting answer. In other words, it is problematic unless you assume that unelected ex-lawyer judges have superior moral antennae to your average voter and that their judicial verdict on rights issues is better - morally better - than the electorate's majority verdict.

And of course there are further difficulties about not according people a right to participate in key public decisions (think same-sex marriage, think when tobacco companies can advertise, think every major Charter decision since 1982), this denied right to participate seemingly lying at the core of treating individuals as autonomous, 
respect-deserving agents - a core pre-supposition of the modern human rights movement. ${ }^{13}$

So there are all the variants of objections related to how judges garner too much power under these instruments, how they themselves decide rights issues on a procedural, count-heads, majority rules basis (five votes beat four, full stop), as well as the straight-out consequentialist objection to bills of rights that says that in a well-functioning democracy legislators (on average, over time) do at least as well as unelected judges in achieving rights-respecting outcomes - which happens to be my view. And such legislators have considerably more legitimacy to be making these decisions than judges — which procedural buttressing point is also my view as it happens.

For the rest of this paper it is only that last consequentialist claim that will be my focus, the one arguing that elected legislators do at least as well as unelected judges in producing rights-respecting outcomes. And I will now confine myself to freedom of the press issues, or at least the subset of such issues that covers hate speech and defamation.

My claim will be that Australia, without any sort of national bill of rights at all, has at least as much press freedom as does Canada with its Charter.

Let me start with hate speech laws. Even a passing acquaintance with the Mark Steyn-Macleans saga with section 13 of the Canadian Human Rights $A c t^{14}$ (and various provincial equivalents) would suffice to show that hate speech laws can and do have an effect on the press, on what it might or might not be able to publish, and concomitantly on what can be thought of as the "chilling effect" of the mere threat of being dragged before some human rights commission where the complainant has every single dollar of his or her legal costs paid for by the taxpayer while the accused — the party alleged to have transgressed these hate speech provisions - has to pay his or her own way.

Put more bluntly, even if you end up winning you lose. Steyn and Macleans eventually had every single legal action against them dropped or ended or dismissed and yet they were out of pocket very large sums

13 This is the basis on which Jeremy Waldron argues against constitutionalized bills of rights. See, e.g., Jeremy Waldron, Law and Disagreement (Oxford: Oxford University Press, 1999) and "The Core of the Case Against Judicial Review" (2006) 115 Yale L.J. 1346. My differently focused but largely sympathetic analyses of Waldron are in "Jeremy Waldron and the Philosopher's Stone" (2008) 45 San Diego L. Rev. 133 and "The Travails of Justice Waldron" in Grant Huscroft, ed., Expounding the Constitution: Essays in Constitutional Theory (New York: Cambridge University Press, 2008) 161.

14 R.S.C. 1985 , c. H-6. 
indeed. I had originally written that those costs were well into six figures but a friend and former lawyer colleague of mine on Bay Street laughed at me when he read that and said that I had been out of practice for too long. He told me that the cost to Macleans or its insurers probably hit seven figures. Since then I have had even better information that the costs to them were about $\$ 2.5$ million.

No one who cares about a free press can pretend that sort of outcome does not deter those who lack the deep pockets of Macleans. Or at any rate, if you can make that claim with a straight face then in my view you ought to move to Los Angeles and look for acting work.

So let us look more closely at the state of hate speech laws in Canada, assuming as I do that any such laws do affect the scope of a free press to publish things many would consider part of the give-and-take of life in a democratic polity.

We can simplify things by separating criminal and non-criminal hate speech restrictions. Only the latter is likely to be relevant to a discussion of freedom of the press, though the leading Supreme Court of Canada cases, respectively, are R.v. Keegstra ${ }^{15}$ (in the criminal realm) and Canada (Human Rights Commission) v. Taylor ${ }^{16}$ (in the civil).

In Taylor, a 5-4 majority decision, the Supreme Court upheld the constitutionality of the section 13 regulation of what was considered hate speech, under which civil remedies are available aimed at compensating complainants and discouraging speakers outside the criminal law. In brief, the majority held that section 13 infringed the freedom of expression guarantee but that this infringement was justifiable under section 1 of the Charter, the abridging provision. Chief Justice Dickson for the majority pointed to such factors as the reduced worth of hate speech, the fact the remedies were civil (not penal) in nature and the importance of the goal of protecting minorities in arguing that the section 13 free speech infringement was justified. Meanwhile then Justice McLachlin, in her dissent, disagreed, arguing that section 13 gave the Human Rights Commission too much discretion, that it had a "chilling effect", and that the restriction was framed in overbroad terms.

For our purposes one single and immediate point to make is that the Charter, or more accurately put "the interpretation of some vague, amorphous rights guarantee and equally indeterminate reasonable limits

15 [1990] S.C.J. No. 129, [1990] 3 S.C.R. 697 (S.C.C.).

16 [1990] S.C.J. No. 131, [1990] 3 S.C.R. 892 (S.C.C.) [hereinafter "Taylor"]. 
provision" by a majority of the then top Canadian judges, did nothing to extend freedom of the press.

If you dislike section 13 the judges let you down. If you like section 13 they ended up adding nothing to the equation. Or rather, they added nothing other than what follows from the assumption that the answers to all political disputes can be (and should be) found by vetting laws against constitutionalized rights provisions (as interpreted by a committee of exlawyers), an assumption open to serious doubt. ${ }^{17}$ And one that makes it harder to repeal such legislation once the top judges, even on a 5-4 basis, have given it a tick of being in accord with what (they happen to think, by majority vote) are people's timeless, transcendent fundamental rights.

I am delighted to say that at the final stages of preparing this paper, a private member's bill in Canada to rid it of section 13 was passed through the House of Commons and now only awaits passage through the unelected Senate - which is close to a certainty in my view before it will be repealed. And that repeal will have been accomplished the way it should be in my view, by the elected legislature not by the unelected judges.

I am also aware that the Whatcott case $^{18}$ has been argued at the Supreme Court, with the decision due in the not too distant future. Whatcott involves a constitutional challenge to Saskatchewan's section 14(1)(b) Saskatchewan Human Rights Code ${ }^{19}$ hate speech law, on the basis that it infringes the Charter's section 2 freedom of expression and/or freedom of religion guarantees. And I realize that a decision in Whatcott to invalidate Saskatchewan's hate speech law may conceivably even involve the justices saying that Taylor is now bad law.

But you should realize that this is at core a philosophical, political and moral dispute grounded in competing versions of why free speech and a free press matter, that unelected top judges have absolutely no extra expertise in such matters, that the political, democratic system could deliver either the pro- or anti-section 13 outcomes, and that if anything the Charter, once a precedent like Taylor is in place, makes repeal considerably more difficult. It has a tendency to lock in legislation.

Let me try to support those claims by turning to Australia. As it happens, there is a fairly close analogy there to the Mark Steyn saga. A

17 See, for example, Adam Tomkins, "In Defence of the Political Constitution" (2002) 22 Oxford J. Legal Stud. 170.

18 Saskatchewan (Human Rights Commission) v. Whatcott, appeal heard and reserved October 12, 2011, [2010] S.C.C.A. No. 155 (S.C.C.) [hereinafter “Whatcott"].

19 S.S. 1979, c. S-24.1. 
newspaper columnist, Andrew Bolt, was taken to court under the 1995 amendment to the Racial Discrimination $A c t^{20}$ that created section $18 \mathrm{C}^{21}$ This section, in an Orwellian way, makes some conduct unlawful, but not a criminal offence. It does so if your speech or act "is reasonably likely ... to offend, insult, humiliate or intimidate" others, and done because of their race (among other things). There is then section 18D, which gives exemptions if what you said was done reasonably and in good faith, including as part of a fair comment on a matter of public interest.

Basically this is an Australian national statutory provision that imposes non-penal hate speech restrictions. After a trial at first instance Mr. Bolt and the Herald Sun newspaper lost. (The opinions voiced here related not to demographics and Islam but rather to affirmative action benefits flowing to self-identifying Aboriginals who appeared, genetically, to have little Aboriginal blood.)

The Australian statutory provision looks less broad than Canada's hate speech provisions, and seemingly has stronger built-in speech protecting defences. But the first instance Australian judge did not interpret the statute that way. For instance, the judge interpreted the section 18C "reasonably likely to offend" test to be one that is assessed by reference to some objective member of those claiming victimhood not by reference to a reasonable member of the community at large - as well as holding that the onus of proof for triggering the section $18 \mathrm{D}$ exemption lay on Bolt, while reading in a "what is deemed to be gratuitously offensive can't claim the exemption" rider. Moreover, as no monetary penalties applied - the remedy was simply a judge-dictated pseudo-apology having to be run by the paper - the newspaper insurers refused to appeal, though my publicly stated newspaper column opinion at the time was that Bolt would have won an appeal.

In Australia too you can see that the real speech inhibitor is the chilling effect of the threat of expensive litigation where complainants have their costs covered and the newspaper and writer do not.

My comparative point is that press freedom is no less protected in Australia. If, like me, you dislike hate speech laws, you gain some comfort from the fact the Australian Opposition party has pledged in unequivocal terms to repeal at least most of these provisions while simultaneously to buttress the section $18 \mathrm{D}$ defences, and has done so

$20 \quad$ Racial Discrimination Act 1975 (Cth).

21 See Eatock v. Bolt, [2011] FCA 1103 (F.C.A.). 
more directly and overtly than Mr. Harper's Tories did, and without hoping for any cover from the courts.

And if you noticed that Mr. Bolt lost in Australia while the Human Rights Commission actions against Mr. Steyn were all ultimately dismissed (in Ontario on the basis of that Commission having no jurisdiction), you need also to consider that in Australia the Bolt case is virtually the only civil hate speech action there has been while in Canada there have been many, with many accused (if we can use that word) losing - including the stand-up comedian Guy Earle in British Columbia.

And in more general terms you should likewise bear in mind the need to avoid falling victim to the fallacy of the frozen legislature assumption, the vague notion that when it comes to rights and respecting rights, the output of the elected legislature in Canada was somehow frozen as of 1982, and so had there never been the Charter no advances on the rights front would ever have emanated from a bill of rightslacking legislature these past 30 years - a nonsense when you specifically articulate the point but a not unheard of implicit assumption from Charter defenders.

I repeat, then, that from any perspective - either in favour of section 13 type hate speech laws or against them - a comparison with Australia does not indicate that the Charter has improved freedom of the press. If you see this issue in terms of having to make a debatable, contestable social policy line-drawing call, and one where a committee of ex-lawyers has not a scintilla of extra moral, political or philosophical expertise, then that is hardly surprising.

What about defamation laws though, an area of law with obvious implications for freedom of the press? Let me start this time with Australia, which sits somewhere between the U.S. and the U.K. in striking the balance between the competing social goods or goals of protecting people's reputations from attacks by others (on the one hand) and the desire to leave people with lots of scope to pass comment on others' conduct and character (on the other). Obviously any balance struck needs to give some weight to protecting people's characters from at least knowingly and maliciously false and outrageous slanders. Likewise, any balance needs to concern itself with the bad consequences that might flow if speakers need dead certainty and rock-solid proof before making claims, of the dangers of stifling not just false allegations but also true ones. 
Put differently, there is a world of difference between something being true and one's being able to prove it is true in a court of law where the onus of proof is on you (the defamation defendant) to prove it.

We are talking, again, about where to draw highly debatable, contestable social policy lines seeking to balance two social goods that are in conflict. The Americans go further than anywhere else in favouring the wide-open speech side of the ledger, especially when the allegations are against public figures - though even there a knowingly false and malicious allegation will lead to a successful defamation action (if you prove as much). Meanwhile the traditional British balance gives considerably more weight to protecting people's reputations, to the point that its courts have on occasion been characterized in terms of their receptivity to "libel tourism".

I am revealing no secrets when I point out that in purely legal terms the U.S. balance gives the press more scope than anywhere else to write things about people without fear of a lawsuit, even things that on occasion may prove to be unwarranted or false. Of course if we cast our gaze up from the purely legal and consider as well cultural factors such as the ethos of the press (and I think now of the British tabloid press) and its willingness to pay significant defamation damages to the odd litigant in order to achieve million-plus sales, then matters are not nearly so clear as to whether the press in the U.S. or the U.K. is more apt "to speak truth to power" (and to puffed up, holier-than-thou celebrities).

But my point, again, is that a comparison of Canada to Australia vis$\grave{a}$-vis the defamation law regime in each jurisdiction gives us no grounds for thinking the Charter does anything at all to promote a more rightsrespecting outcome.

First, and to repeat myself, it is a highly contestable and everywhere debated issue as to which drawn line is most rights-respecting or best or least bad in this exercise of balancing reputation against scope to publish what sometimes may be false claims.

Second, if we simply assume that the U.S. end of the spectrum, the more scope for speech end, is preferable, then Australia does at least as well as Canada - possibly better.

For those who would like a brief, up-to-date account of the law of defamation in Australia, the one provided by Justice Peter Applegarth, a judge of the Supreme Court of Queensland, is the place to look. ${ }^{22}$ Let me

22 See Justice Peter Applegarth, "Distorting the Law of Defamation" (2011) 30 U.Q.L.J. 99 [hereinafter "Applegarth"]. 
here give away the punch line and tell you that in the 1997 case of Lange v. Australian Broadcasting Corp. ${ }^{23}$ the High Court of Australia created a special category of common law qualified privilege for communications about government and political matters - meaning a defence for speakers and publishers even where truth cannot ultimately be proven in court (though some states in Australia already had a statutory defence of qualified privilege that covered this). Basically, a publisher has to act reasonably in the circumstances and without malice to trigger this privilege or defence related to governmental or political matters. And "reasonable in the circumstances" means the publisher has "reasonable grounds for believing that the imputation was true, took proper steps, so far as they were reasonably open, to verify the accuracy of the material and did not believe the imputation was untrue". ${ }^{24}$ And this is in addition to the traditional defence of qualified privilege that does not require reasonableness, and in some circumstances gives wider protection ${ }^{25}$ (for example, as regards matters of public interest outside government and political matters).

This Lange defence superseded a "constitutionalized" defamation defence and is related to what in Australia is known as the implied right to freedom of political communication, ${ }^{26}$ albeit in a complicated and contentious way. Luckily for our purposes we can leave the position in Australia at that.

Meanwhile the state of Canada's Charter-driven defamation law regime is more or less this. The more traditional British-style balance, giving a good deal more weight to protecting reputation than does U.S. defamation law, was moved or altered in Grant v. Torstar Corp. ${ }^{27}$ along the spectrum a bit towards the U.S. position (though still falling a good deal short of where the U.S. line is drawn). The Supreme Court of Canada opted for a new rule "that gives greater scope to freedom of expression while offering adequate protection of reputation ... [this new defence requiring publishers to] establish that they acted responsibly in attempting to verify the information [published related to] a matter of public interest" ${ }^{28}$ Call this the "defence of responsible communication", requiring judges to think the topic is a matter of public interest and that

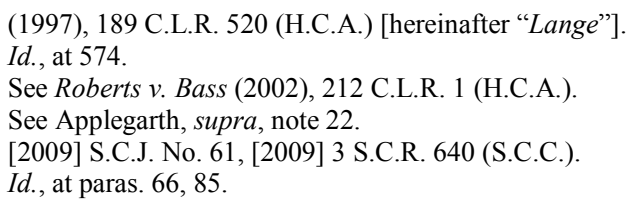


the publisher was diligent in trying to verify the allegations (given the circumstances), and you can see that this new defence will sometimes offer protection when published claims ultimately prove to be untrue or what is not quite the same, when the publisher is unable to prove their truth in court. Something similar applies to wholly private law cases not directly governed by the Charter, because we are told in WIC Radio Ltd. v. Simpson ${ }^{29}$ that the common law (i.e., purely judge-made law) is to be guided by Charter values.

Meantime, in a case that is no doubt of interest to journalists, the Supreme Court held in 2010 that there is no basis for recognizing a classbased constitutional or quasi-constitutional journalist-source privilege under either the Canadian Charter or the Quebec Charter. ${ }^{30}$

So that gives you a bit of detail as regards the state of the defamation law regimes in Canada and Australia. But my larger point is that both countries' regimes fall easily within what the vast preponderance of people would consider some rights-respecting core. And for pro-asmuch-scope-to-speak-as-possible people like me, neither country matches the U.S. but Australia does at least as well as Canada, possibly better. Put more bluntly, bill of rights-lacking Australia does every bit as well as Charter-dominated Canada in terms of defamation law in giving people lots of scope to speak their minds.

Precisely the same goes for hate speech laws in both countries as they relate to freedom of the press, as we have seen.

My conclusion then, one that will be surprising to some I suspect, is that Canada's entrenched Charter adds nothing to freedom of the press if Canada is being compared to its closest constitutional cousin Australia, and so tangentially to what it might have looked like today without the Charter.

Of course that conclusion rests on my preference for an extensive, hardly-limited-at-all protection of free speech entitlements, and nothing about that preference is self-evidently best or correct. It will vary for each of us. More tellingly, perhaps, the same person's preference for an expansive, hardly-limited-at-all protection for this right will not always translate to that right or to all rights, or to all Charter-enumerated rights. For each of us, where we draw the line will vary from right to right. The same goes for the top judges. The same goes for the elected legislators.

29 [2008] S.C.J. No. 41, [2008] 2 S.C.R. 420 (S.C.C.).

Globe and Mail v. Canada (Attorney General), [2010] S.C.J. No. 41, [2010] 2 S.C.R. 592 (S.C.C.). Charter of Human Rights and Freedoms, R.S.Q. c. C-12. 
That means that those readers who think the free speech right works particularly well for my argument here, because the judges have allowed more inroads or limitations on it than they might have, or than they have as regards some other favoured right, still would have to show that all rights ought always to be given the hardly-limited-at-all treatment. (And few think this and anyway that case, in my view, is nearly impossible to make in any persuasive way.) Or they would have to show that where the Canadian judges happened to have drawn these contestable lines across the whole range of enumerated rights is better than where elected legislatures would have drawn them, and better by a big enough margin to outweigh the democratic illegitimacy attaching to a "judges have the last word" procedure. (Another tough argument in my view.)

The undeniable truth is that smart, well-informed, reasonable people disagree about all those social policy line-drawing calls articulated in the language of rights. It is as simple as that. What differs between Australia and Canada is whether it is the top judges or the elected legislature that has, for all practical purposes, the final word on these issues. 
